\title{
SOCIETY IN THE 21st CENTURY: THE THEORY OF THE AGE OF COLLECTIVE INDIVIDUALISM
}

\author{
Andreas Herteux \\ Erich von Werner Society, Birkenfelder Straße 3, 97842 Karbach, Germany \\ DOI: 10.46609/IJSSER.2020.v05i06.008 URL: https://doi.org/10.46609/IJSSER.2020.v05i06.008
}

\begin{abstract}
- Humanity has entered a new age: that of collective individualism

- The new era was initiated by the change of times or is being dynamised by it

- This dynamic makes development difficult to manage, predict or control

- The age is characterized by a steady disintegration of global societies into individual milieus

- These milieus are characterised by different world views, values and behavioral patterns and inevitably come into conflict with each other (milieu struggle)

- At the same time, there is an unstoppable tendency towards individualisation, which is driven by behavioral capitalism, the modern stimulus society and homo stimulus, among other things

- This tendency towards individualization leads to the embedding of the individual in his own world

- Between the role as an individual and that as part of a milieu, a so-called identification dissonance can arise
\end{abstract}

Keywords: Homo stimulus, Kollektiver Individualismus, Behavioral Capitalism, Stimulus Society, Value Capitalism, Milieu Struggle, Identification dissonance

\section{INTRODUCTION}

In the history of mankind there have been numerous turning points and entries into new epochs and ages. Often the transitions were gradual, were not perceived as such and were only recognized as a new era in retrospect. Exactly this - and this is the core thesis of this contribution - is happening again at the moment. Humanity is about to enter a new age: that of collective individualism. 


\section{What is collective individualism?}

But what is meant by this term? Collective individualism is understood to be an individualism in which the individual is embedded in such a way that individual self-development can take place within a framework that is not or barely visible. $\mathrm{In}^{1}$ parallel, it is the designation of a period of time. In order to approach this definition, it is necessary to take a closer look at both social development and the tendency towards individualisation, and yet the view should first of all go a little further.

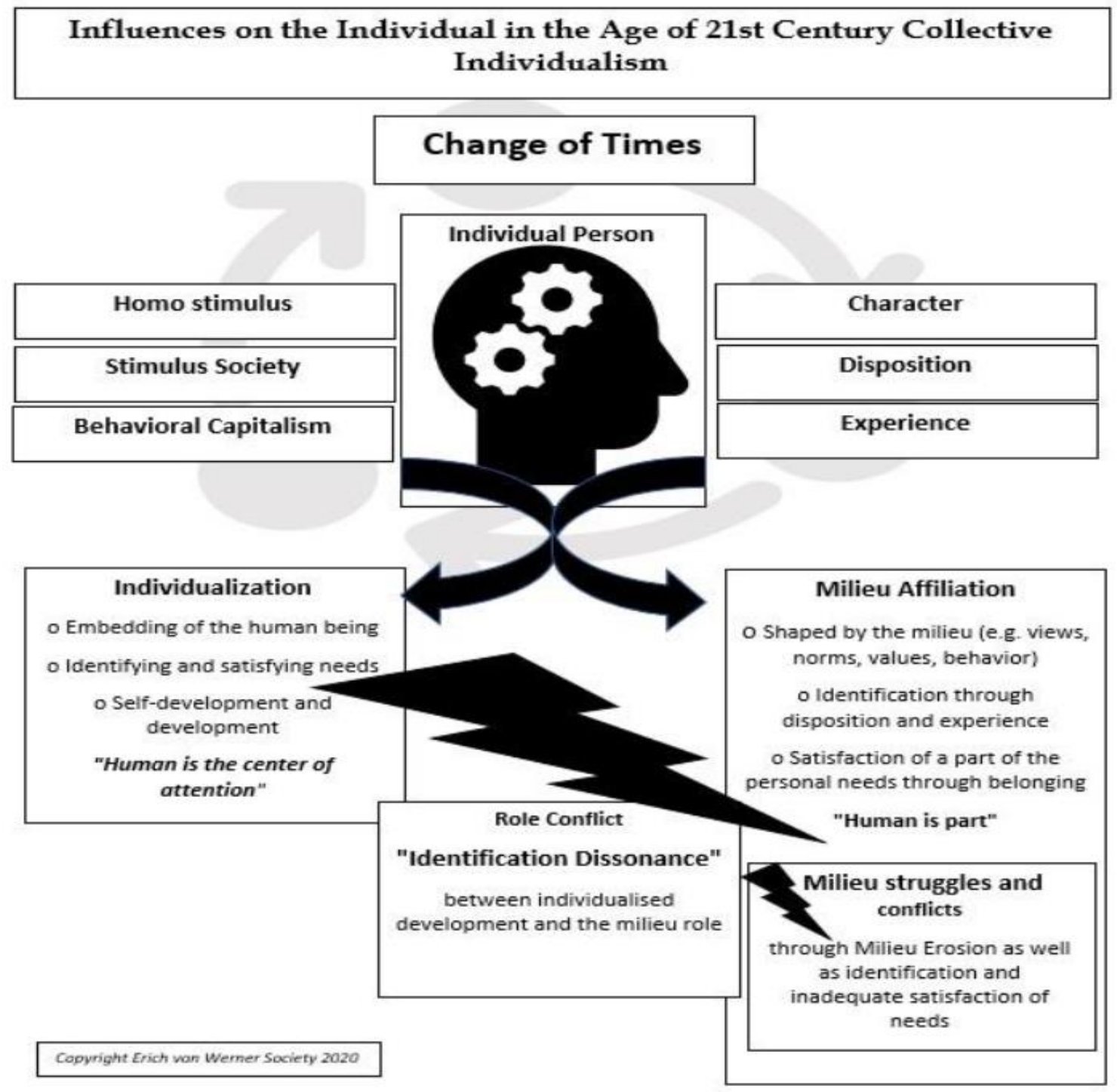

1 Herteux, A. 2020, Grundlagen gesellschaftlicher Entwicklungen im 21. Jahrhundert: Neue Erklärungsansätze zum Verständnis eines komplexen Zeitalters, Erich von Werner Verlag, 01.08.2020, ISBN 978-3948621162 
International Journal of Social Science and Economic Research

ISSN: 2455-8834

Volume: 05, Issue: 06 "June 2020"

\section{What are the roots of collective individualism?}

Collective individualism is ultimately the product of social, economic, political and technological development. In recent years, this has not been a continuous and straightforward process, but has taken place in leaps and bounds. The process can be summarised succinctly under the term "change of times". This is a period of time in which its individual elements dynamically influence each other in such a way that they can bring about a reorganisation of the previous (global) power relations.

These elements are:

1.) Dealing with technological progress (e.g. digitalisation, behavioral capitalism, homo stimulus, biotechnology, AI, optimisation of the human being)

2.) the emergence of new competitors on world markets (e.g. Asian countries)

3.) Weakness of the Western world (e.g. through instability, dwindling confidence in existing orders, loss of competitiveness or China's political rise)

4.) Changes in environmental conditions (e.g. through climate change, pandemics, resource exploitation or environmental destruction)

5.) Lack of prospects for a part of humanity (e.g. due to overpopulation or unsatisfied basic and security needs) ${ }^{2}$

Whether it is now necessary to bundle all points into one term may be left open. But it seems to make sense in order to approach the complexity of the change processes and to give it a handy, popularly usable form. Same as; each of these developments exerts massive pressure on the existing structures.

\section{Erosion of social milieus}

If one focuses on social development, it is noticeable that there is a measurable erosion of social milieus. Or to put it more simply: societies are disintegrating into ever smaller realities. A phenomenon that can be measured worldwide, both in the industrialised countries and in the developing countries, often according to comparable patterns, and thus represents a weighty indication of the impact of the change of times. ${ }^{3}$

2 Herteux, A. 2020, Grundlagen gesellschaftlicher Entwicklungen im 21. Jahrhundert: Neue Erklärungsansätze zum Verständnis eines komplexen Zeitalters, Erich von Werner Verlag, 01.08.2020, ISBN 978-3948621162

3 cf. Barth, Betram und weitere - Praxis der Sinus-Milieus® - Gegenwart und Zukunft eines modernen Gesellschafts- und Zielgruppenmodells, Springer-Verlag“, 24.10.2017, 978-3-658-19335-5 


\section{International Journal of Social Science and Economic Research}

ISSN: $2455-8834$

Volume: 05, Issue: 06 "June 2020"

Social milieus are ultimately defined by the fact that those who belong to them share specific world views, patterns of behaviour, norms, values or ideas about a good life. Now that there are more and more realities of life, the assumption that there is an increased potential for conflict between different milieus seems a legitimate one.

\section{Milieu struggles and conflicts}

The resulting disputes can be summarized under the term milieu struggle. ${ }^{4}$ This means that conflicts arise between the realities of life (milieus) of a society (or several societies), which are fought out actively or passively. The milieu conflict is always preceded by milieu conflicts. Milieu conflicts are conflicts that arise when the needs of the people who form the milieu remain partially or completely unfulfilled or when the self-image of the reality of life is attacked. The dangerous thing about these milieu conflicts and struggles is that they can become charged and then - apparently irrationally - discharge themselves, ultimately depending on the possibilities of articulation and the influence of a life possibility. How else would the election of a President Trump, who made use of precisely these mechanisms, have been possible? The theory of milieu struggle does not claim to be a comprehensive explanation for modern social conflicts, but it could be useful as a complementary pattern of interpretation and classification and could be discussed.

\section{Social and individual level}

This, however, does not explain the definition of collective individualism, since the social level only has the function of inhibiting the completion of the process of individualisation, the existence of which should not be in dispute, and it is therefore necessary to take a closer look at the individual level.

This individual level is, in addition to continuous development, also confronted with the dynamism of changing times. Two individual processes will be picked out: behavioral capitalism and the emergence of homo stimulus or the modern stimulus society. Both are mutually dependent and cannot be separated from each other.

\section{Behavioral capitalism}

Behavioral capitalism is a variety of capitalism in which human behaviour becomes the central factor in the production and supply of goods and services. ${ }^{5}$

4 Herteux, A. 2020, Grundlagen gesellschaftlicher Entwicklungen im 21. Jahrhundert: Neue Erklärungsansätze zum Verständnis eines komplexen Zeitalters, Erich von Werner Verlag, 01.08.2020, ISBN 978-3948621162

${ }^{5}$ Herteux, A. (2019) - Erste Grundlagen des Verhaltenskapitalismus: Bestandsaufnahme einer neuen Spielart des Kapitalismus, 11th edition, Erich von Werner Verlag, 2019, ISBN 978-3981900651, DOI 10.5281/zenodo.3469587 
The key to understanding this new form of capitalism is to view human behaviour as a usable raw material. From this, it is possible to derive, as far as it can be obtained in sufficient quantities, on the one hand the needs of people, but also forecasts for future action. On the basis of this raw material, products and services can therefore be produced that meet the needs or future behaviour. It is therefore hardly surprising at what speed large technology corporations such as Amazon, Facebook or Google emerged and began to collect data, use behaviour according to capitalist methods and embed people piece by piece. Algorithms and automation made this possible, which people of earlier decades would not have been able to do at all, and only in this way could the raw material become a production factor.

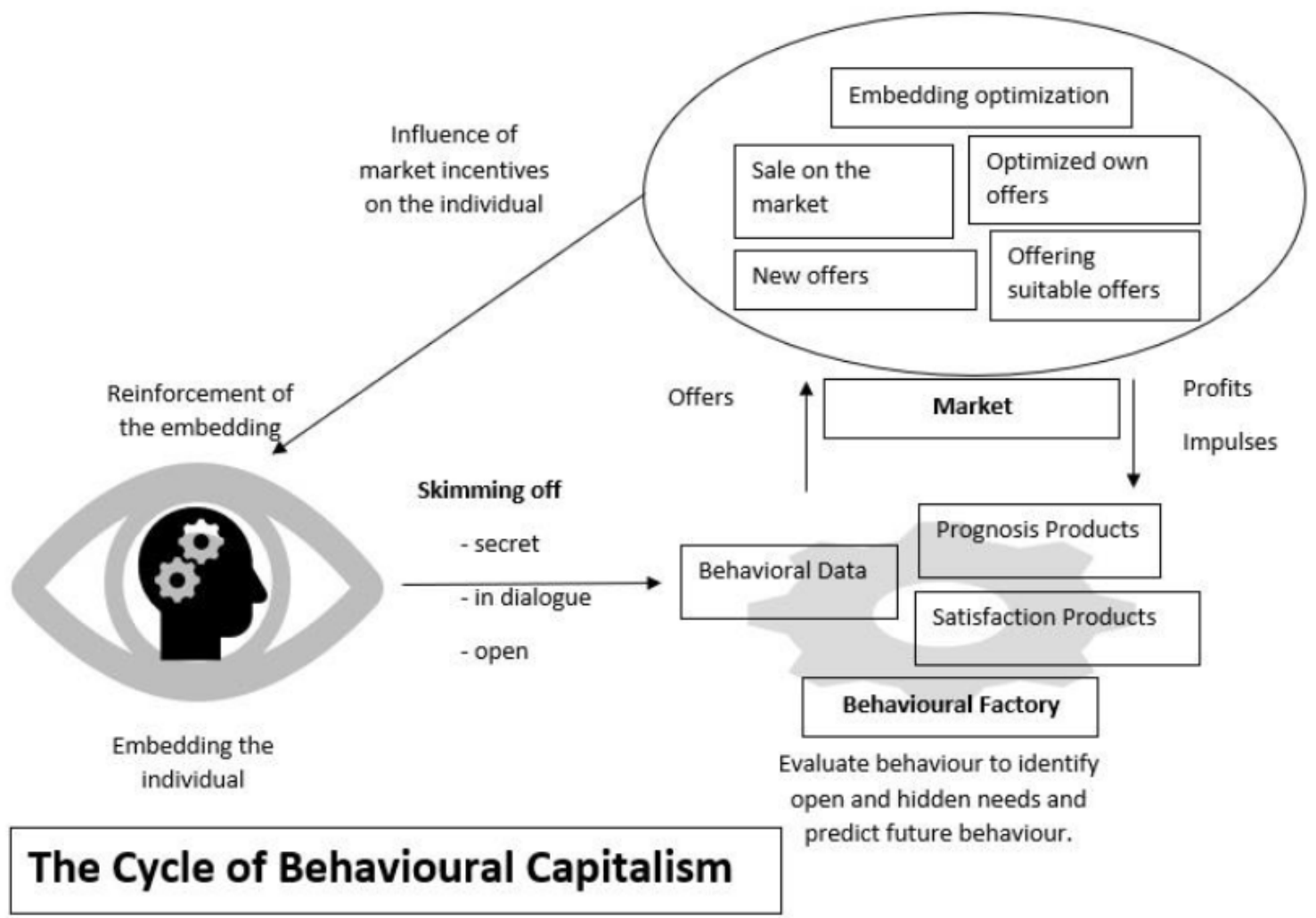

Alle Rechte Erich von Werner Society 2019

- Herteux, A. (2019) First Foundations of Behavioral Capitalism: A New Variety of Capitalism Gains Power and Influence Erich von Werner Verlag, 25.09.2019, ISBN-13: 978-3981900675, DOI 10.5281/zenodo. 3469568

- Herteux, A. (2019). Behavioral Capitalism - A New Variety of Capitalism Gains Power and Influence. Journal of Applied Business and Eco-nomics, 21(9). https://doi.org/10.33423/jabe.v21i9.2688Herte

- Herteux, Andreas - International Journal of Social Science and Economic Research (IJSSER): BEHAVIORAL CAPITALISM AND SURVEILLANCE CAPITALISM - A COMPARISON OF TWO INTERPRETATIONS OF A DEVELOPMENT OF CAPITALISM, Volume 12/2019, Page 7253-7268, published 12/2019, ISSN: 2455-8834 
International Journal of Social Science and Economic Research

ISSN: $2455-8834$

Volume: 05, Issue: 06 "June 2020"

Nevertheless, it would be fatal to regard this process as one-sided, because in the end the individual also wants this embedding, because it serves to identify and fulfil his or her own needs and is therefore usually demanded actively and passively by the users. It therefore makes no sense to interpret the embedding process as a manipulation mechanism, even though it could be misused for this purpose.

The definition of collective individualism states that the individual is embedded in such a way that individual self-development can take place within a framework that is not or hardly visible. Behavioral capitalism fulfils precisely this criterion: self-fulfilment becomes possible, but is guided by non-visible algorithms.

There is no doubt that behavioral capitalism therefore has an important role to play in a new age, and yet the analysis would be incomplete if it were not for the modern stimulating society and homo stimulus that have made this success possible.

\section{Modern stimulating society and homo stimulus}

A modern stimulus society is a group of individuals who are exposed to influencing, usually artificially generated stimuli at a high frequency and who have difficulty or difficulty in escaping them, or in some cases do not want to.

A homo stimulus is understood to be a person who is conditioned in such a way, who is used to a permanent confrontation with highly frequented, short as well as artificial stimuli and who can or wants to evade them hardly or only partially. On the contrary, certain stimuli are often demanded or a corresponding stimulus dialogue is initiated. ${ }^{6}$

What sounds abstract can be solidified with a look at the massively increasing usage figures of online portals that offer exactly those stimuli. ${ }^{7}$

\footnotetext{
${ }^{6}$ Herteux, A. , Homo stimulus: Fundamentals of human adaptation and development in the age of collective individualism,. Erich von Werner Verlag, 12 February 2020, ISBN-13: 978-3948621124, DOI 10.5281/zenodo.3666616

- Herteux, A (2019) - International Journal of Social Science and Economic Research (IJSSER): THE HOMO STIMULUS: THE CREATION OF A NEW HUMAN BEING - SHAPED BY THE STIMULUS SOCIETY AND BEHAVIORAL CAPITALISM - IN THE AGE OF COLLECTIVE INDIVIDUALISM. Int. j. of Social Science and Economic Research, 5(1), 207-226. Retrieved from ijsser.org/more2020.php?id=14

${ }^{7}$ In the minute was already 2017 :

- 3.8 million Google search queries

- 47,000 Instagram photo uploads

- 4.1 million YouTube clicks

- 530,000 snapchat shares

- 456,000 tweets on Twitter
} 
Without this decades-long development and conditioning, the success of behavioral capitalism, which relies on these stimuli, would have been unthinkable.

\section{Embedding process}

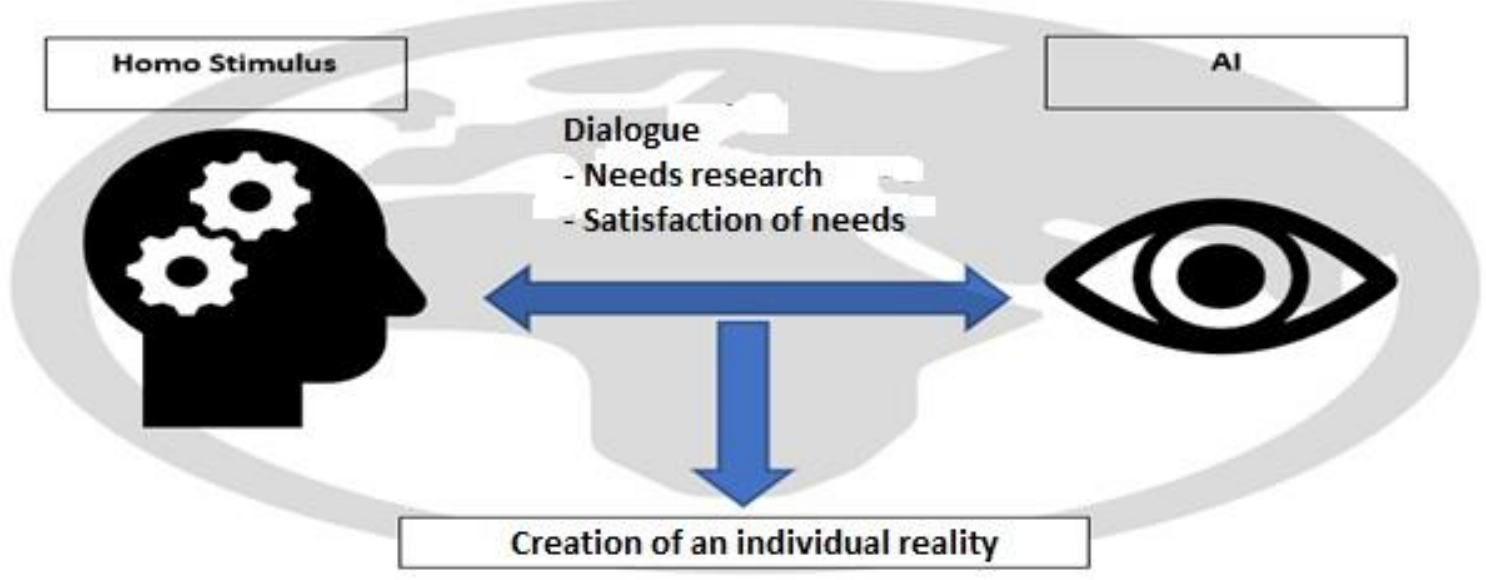

Alle Rechte Erich von Werner Gesellschaft 2019

To sum up, the homo stimulus, the stimulus man, is one who pushes for total individualization, and yet this trend is currently being held back by social development, as not all needs can be met in this new world. Here we can speak of a dissonance of identification.

\section{Modern identification dissonance}

The theory of modern identification dissonance, which presupposes that the erosion of life's realities has become more dynamic and the possibilities for self-development have increased, states that there may be increasing conflicts on the part of the individual with regard to his or her own role as part of a milieu and the personal process of individualisation and embedding, and that these will have a long-term influence on social developments and structures. ${ }^{8}$

\section{Complete and incomplete collective individualism}

8 Herteux, A. 2020, Grundlagen gesellschaftlicher Entwicklungen im 21. Jahrhundert: Neue Erklärungsansätze zum Verständnis eines komplexen Zeitalters, Erich von Werner Verlag, 01.08.2020, ISBN 978-3948621162 


\section{International Journal of Social Science and Economic Research}

ISSN: $2455-8834$

Volume: 05, Issue: 06 "June 2020"

Because of this conflict, collective individualism is also divided into complete and incomplete collective individualism: ${ }^{9}$

Complete collective individualism is the product of a total process of individualisation, no longer inhibited by milieu struggles and other restrictions. It is the pure form, or rather the ideal of collective individualism and is unlikely to be achieved in the 21 st century.

Incomplete collective individualism is a collective individualism in which the process of individualisation and embedding is inhibited or slowed down, becomes or cannot be completed completely. Typical factors of this inhibition would be e.g. milieu struggles or identification dissonance. It is therefore a current form of reality. The collective individualism of the $21 \mathrm{st}$ century will be an incomplete one.

\section{Glossary}

This glossary summarizes the central terms of this monograph. At the same time, it includes definitions that are of limited relevance to the present work, but which can play an important role for further discussion and consolidation, in the sense of an overall view of social developments.

- Homo stimulus

A homo stimulus is understood to be a person who is conditioned in such a way, who is used to a permanent confrontation with highly frequented, short as well as artificial stimuli and who can or wants to evade them hardly or only partially. On the contrary, certain stimuli are often demanded or a corresponding stimulus dialogue is initiated.

\section{- Identification dissonance}

The theory of modern identification dissonance, which presupposes that the erosion of life's realities has become more dynamic and the opportunities for self-development have increased, states that there may be increasing conflicts on the part of the individual with regard to his or her own role as part of a milieu and the personal process of individualisation and embedding, and that these will have a long-term influence on social developments and structures

\section{- Collective individualism}

Collective individualism is understood to be an individualism in which the individual is embedded in such a way that individual self-development can take place within a framework that is not or hardly visible. Collective individualism is at the same time the designation of a period of time. Basically two variants can be distinguished:

9 Herteux, A. 2020, Grundlagen gesellschaftlicher Entwicklungen im 21. Jahrhundert: Neue Erklärungsansätze zum Verständnis eines komplexen Zeitalters, Erich von Werner Verlag, 01.08.2020, ISBN 978-3948621162 


\section{○ Complete collective individualism}

Complete collective individualism is the product of a total process of individualisation, no longer inhibited by milieu struggles and other restrictions. It is the pure form, or rather the ideal of collective individualism and is unlikely to be achieved in the 21 st century.

○ Incomplete collective individualism

Incomplete collective individualism is a collective individualism in which the process of individualisation and embedding is inhibited or slowed down, becomes or cannot be completed completely. Typical factors of this inhibition would be e.g. milieu struggles or identification dissonance. It is therefore a current form of reality. The collective individualism of the $21 \mathrm{st}$ century will be an incomplete one.

\section{- Milieu fight}

Milieu struggle means that conflicts arise between the realities of life (milieus) of a society (or several societies), which are fought out actively or passively.

\section{- $\quad$ Milieu Conflict}

Milieu conflicts always precede milieu conflicts.

Milieu conflicts are conflicts which are justified when the needs of the people who form the milieu remain partially or completely unfulfilled or when the self-image of the reality of life is attacked.

- $\quad$ Modern stimulating society

A modern stimulus society is a group of individuals who are exposed to influencing, usually artificially generated stimuli at a high frequency and who have difficulty or difficulty in escaping them, or in some cases do not want to.

\section{- Behavioral capitalism}

Behavioral capitalism is a variety of capitalism in which human behaviour becomes the central factor in the production and supply of goods and services.

- $\quad$ Value capitalism

Value capitalism [the value market economy] is an economic order in which values become a factor of production.

- $\quad$ Change of Times 


\section{International Journal of Social Science and Economic Research}

ISSN: $2455-8834$

Volume: 05, Issue: 06 "June 2020"

A change of time is understood to be a period of time in which its individual elements dynamically influence each other in such a way that they can bring about a reorganisation of the previous (global) power relations.

These elements are:

6.) Dealing with technological progress (e.g. digitalisation, behavioral capitalism, homo stimulus, biotechnology, AI, optimisation of the human being)

7.) the emergence of new competitors on world markets (e.g. Asian countries)

8.) Weakness of the Western world (e.g. through instability, dwindling confidence in existing orders, loss of competitiveness or China's political rise)

9.) Changes in environmental conditions (e.g. through climate change, pandemics, resource exploitation or environmental destruction)

10.) Lack of prospects for a part of humanity (e.g. due to overpopulation or unsatisfied basic and security needs)

\section{REFERENCES}

Herteux, A. 2020, Grundlagen gesellschaftlicher Entwicklungen im 21. Jahrhundert: Neue Erklärungsansätze zum Verständnis eines komplexen Zeitalters, Erich von Werner Verlag, 01.08.2020, ISBN 978-3948621162

Herteux, A. (2019) First Foundations of Behavioral Capitalism: A New Variety of Capitalism Gains Power and Influence Erich von Werner Verlag, 25.09.2019, ISBN-13: 9783981900675, DOI 10.5281/zenodo.3469568

Herteux, A. (2019) Erste Grundlagen des Verhaltenskapitalismus: Bestandsaufnahme einer neuen Spielart des Kapitalismus Erich von Werner Verlag, 25.09.2019, ISBN-13: 9783981900651, DOI 10.5281/zenodo.3469587

Herteux, A. (2019), Homo stimulus: Grundlagen menschlicher Anpassung und Weiterentwicklung im Zeitalter des kollektiven Individualismus. Erich von Werner Verlag, 12. Februar 2020, ISBN-13: 978-3948621124, DOI 10.5281/zenodo.3666616

Herteux, A. (2019) Homo stimulus: Fundamentals of Human Adaptation and Development in the Age of Collective Individualism. Erich von Werner Verlag, 19. Februar 2020, ISBN 9783948621131, DOI 10.5281/zenodo.3675389 